\title{
On the edge of glory (...or catastrophe): regulation, transparency and party democracy in data-driven campaigning in Québec
}

\section{Eric Montigny}

Department of political science, Université Laval, Québec City, Canada, eric.montigny@pol.ulaval.ca

\section{Philippe Dubois}

Department of political science, Université Laval, Québec City, Canada, philippe.dubois.3@ulaval.ca

\section{Thierry Giasson}

Department of political science, Université Laval, Québec City, Canada, thierry.giasson@pol.ulaval.ca

Published on 31 Dec 2019 | DOI: 10.14763/2019.4.1441

\begin{abstract}
The 2018 election marked an organisational change for major political parties in Québec. They have all massively integrated data-driven campaigning practices. This article identifies factors that could explain the increasing pressure to regulate Québec's political parties' uses of large sets of digital voter information. Québec presents an interesting case to study the effects of data-driven campaigning of parties operating in a parliamentary system where privacy protection rules are limited. Based on semi-directed interviews conducted with strategists from the major parties, it also stresses important intra-party changes and challenges for party democracy.
\end{abstract}

Keywords: Data-driven campaigning, Québec, Intra-party change, Privacy, Online campaigns

\section{Article information}

Received: 05 Jul 2019 Reviewed: 04 Nov 2019 Published: 31 Dec 2019

Licence: Creative Commons Attribution 3.0 Germany

Competing interests: The author has declared that no competing interests exist that have influenced the text.

URL:

http://policyreview.info/articles/analysis/edge-glory-or-catastrophe-regulation-transparency-and-party -democracy-data-driven

Citation: Montigny, E. \& Dubois, P. \& Giasson, T. (2019). On the edge of glory (...or catastrophe): regulation, transparency and party democracy in data-driven campaigning in Québec. Internet Policy Review, 8(4). DOI: 10.14763/2019.4.1441

This paper is part of Data-driven elections, a special issue of Internet Policy Review guestedited by Colin J. Bennett and David Lyon. 


\section{INTRODUCTION}

For the last 50 years, Québec politics has been characterised by a lasting two-party system based on a dominant divide between the Yes and No options to the project of political independence from the rest of Canada of the 8.4 million people in Canada's predominantly Francophone jurisdiction (Pelletier, 1989). Following the failure of the 1995 referendum, the erosion of this divide led to an openness of the partisan system and the arrival of four parties in the Québec National Assembly (Dufresne et al., 2019; Langlois, 2018). With a new party elected to government for the first time since 1976, the 2018 election was one of realignment. The Coalition avenir Québec (CAQ) elected 74 Members of the National Assembly (MNAs). With 31 seats, the former government, the Québec Liberal Party (QLP), received its worst result in 150 years and formed the official opposition. With 10 MNAs each, Québec solidaire (QS), a left-wing party and the Parti québécois (PQ), the historic vehicle for independence, occupied the remaining opposition seats.

Beyond these election results, the 2018 Québec election also marks an organisational change. For the first time, the major parties have all massively adopted what is often referred to as "US" data-campaigning practices. However, when it comes to the use of digital technologies for electoral purposes, the US case is the exception rather than the rule (Enli and Moe, 2013; Gibson, 2015; Vaccari, 2013, p. ix). Indeed, data campaigning, as with other techniques of political communication, are conducted in specific contexts that affect what is accessible, possible and viable (Bennett, 2016; Dobber et al., 2017; Ehrhard et al., 2019; Flanagan, 2010, p. 156).

Not unlike other Canadian jurisdictions, Québec is therefore an interesting case to study the effects of these practices in parties operating in a parliamentary system, while not being subject to privacy protection rules. Moreover, to our knowledge, studies on this subject in a sub-national context are few. In Canada, the majority of the work focuses on federal parties (see for example Bennett, 2018; McKelvey and Piebiak, 2018; Munroe and Munroe, 2018; Patten, 2015, 2017; Thomas, 2015), leaving provincial and municipal levels behind (with the notable exception of Carlile, 2017; Yawney, 2018; and Giasson et al., 2019). Thus, the French-speaking jurisdiction represents, as Giasson et al. (2019, p. 3) argue, one of those relevant but "less obvious" cases to study in order to better understand the similarities and differences in why and how political parties adopt or resist technological innovations. The use of this type of case study also makes it possible to explore the gap between emerging opportunities and the campaigns actually deployed by the parties, beyond the "rhetoric of data-driven campaigning" (see BaldwinPhilippi, 2017, p. 627).

Many factors influence technological innovation in campaigns (Kreiss, 2016). Furthermore, as Hersh indicates (2015), cultural and legal contexts influence political actors' behaviour because types of data that are made available to campaigns shape their perceptions of voters, and therefore their communication practices. According to Munroe and Munroe (2018), political parties may use data as a resource generated in many ways that can be used to guide strategic and tactical decisions. Because parties set up integrated platforms in which personal data on voters are stored and analysed, ethical and political issues emerge (Bennett, 2013, 2015). In most Canadian provinces, including Québec, and at the federal level, parties are not subjected to privacy laws regarding the use and protection of personal data. This absence of a regulatory framework also leads to inadequate self-regulation (Bennett, 2018; Howard and Kreiss, 2010). 
As was the case in many other jurisdictions around the globe, Québec parties were faced with a transparency deficit following the March 2018 revelations of the Cambridge Analytica affair (Bashyakarla et al, 2019; Cadwalladr and Graham-Harrison, 2018). Within hours of the scandal becoming public, political reporters in Québec turned to party leaders to get a better sense of the scope and use of the digital data they were collecting, why they collected them and what this all meant for the upcoming fall elections as well as for citizens' privacy (Bélair-Cirino, 2018). Most claimed that their data collection and analysis practices were ethical and respectful of citizen's privacy. However, none of them agreed to fully disclose the scope of the data they collected nor the exact purpose of these databases.

\section{RESEARCH OBJECTIVES AND METHODOLOGY}

This article examines the increasing pressure to regulate uses of digital personal data by Québec's political parties. First, it illustrates the central role now played by voter personal data in Québec's politics. Second, it presents the current (and weak) legislative framework and how the issue of the protection of personal data came onto the agenda in Québec. At first, many saw this shift has a positive evolution where Québec's parties "caught up" with current digital marketing practices. However, following the Cambridge Analytica affair and revelations about the lack of proper regulation on voter data use, public discourse started casting these technological advancements as democratic catastrophes waiting to happen.

We use three types of data to investigate this context. First, in order to assess the growth in party use of digital voter data, we rely on 40 semi-directed interviews conducted for a broader research project with party organisers, elected officials, activists and advisors of all the main political parties operating in Québec ${ }_{1}$. The interviews, each lasting from 45 minutes to 1-hour were conducted in French just a few weeks before the launch of the 2018 provincial election campaign. Citations presented in this article are therefore translations. The interviewees were selected according to their political representativeness, but also for their high level of electoral involvement. In this article, we only use those responses that relate to digital campaigning and the use of personal information. The citations selected here represented viewpoints shared by at least three interviewees. They illustrate shared perceptions of the evolution of the strategic use of voter personal data in Québec's electioneering.

Second, we also analysed the legislative framework as well as the self-regulatory practices of political parties in Québec in order to measure the levels of regulation and transparency surrounding their use of personal data. To do this, we studied the websites of the four main parties in order to compare their practices.

Finally, we also conducted a media coverage analysis on the issue of how parties engaged in digital marketing. We conducted a keyword search on the Eureka.cc database to retrieve all texts published in the four main daily newspapers published in French in Québec (La Presse, Le Devoir, Le Soleil and Le Journal de Montréal), in the public affairs magazine L'Actualité, as well as on the Radio-Canada website about digital data issues related to politics in Québec. The time period runs from 1 January 2012 to 1 March 2019 and covers three general (2012, 2014 and 2018) and two municipal (2013 and 2017) elections. Our search returned 223 news articles.

What we find is a perfect storm. We saw parties that are massively adopting data marketing at the same time that regulatory bodies expressed concerns about their lack of supervision. In the background, an international scandal made the headlines and changed the prevailing discourse 
surrounding these technological innovations.

\section{NEW DIGITAL TOOLS, A NEW POLITICAL REALITY}

The increased use of digital technologies and data for electioneering can be traced back to the 2012 provincial election (see Giasson et al., 2019). Québec political parties were then faced with a changing electorate, and data collection helped them adapt to this new context. Most of them also experienced greater difficulties in rallying electors ideologically. In Québec, activist, partisan politics was giving way to more political data-marketing (Del Duchetto, 2016).

In 2018, Québec's four main political parties integrated digital technologies at the core of their electoral organisations. In doing so, they aimed to close the technological gap with Canadian parties at the federal level (Marland et al., 2012; Delacourt, 2013). Thus, the CAQ developed the Coaliste, its own tool for processing and analysing data. The application centralises information collected on voters in a database and targets them according to their profile. Developed at a cost of 1 million Canadian dollars, the tool was said by a party strategist to help carry a campaign "with 3 or 4 times less" money than before (Blais and Robillard, 2017).

For its part, QS created a mobilisation platform called Mouvement. The tool was inspired by the "popular campaigns of Bernie Sanders and La France Insoumise in France." 2 Decentralised in nature, the platform aimed to facilitate event organisation, networking between sympathisers, to create local discussion activities, as well as to facilitate voter identification.

The PQ has also developed its own tool: Force bleue. At its official launch, a party organiser insisted on its strategic role in tight races. It would include "an intelligent mapping system to crisscross constituencies, villages, neighbourhoods to maximise the time spent by local teams and candidates by targeting the highest paying places in votes and simplify your vote turnout" (Bergeron, 2018).

Finally, the QLP outsourced its digital marketing and built on the experience of the federal Liberal Party of Canada as well as Emmanuel Macron's movement in France. For the 2018 election campaign, the party contracted Data Sciences, a private firm which "collects information from data of all kind, statistics among others, on trends or expectations of targeted citizens or groups"(Salvet, 2018).

Our interviews with political strategists help better understand the scope of this digital shift that Québec's parties completed in 2018. They also put into perspective the effects of these changes and the questions they raise within the parties themselves.

\section{Why change?}

Party organisers interviewed for this article who advocate for the development of new tools stress two phenomena. On the one hand, the Québec electorate is more volatile and on the other, it is much more difficult to communicate with electors than before. A former MNA notes that today: "The campaign counts. It's very volatile and identifying who votes for you early in the campaign doesn't work anymore. "

With social media, Québec parties' officials see citizens as more segmented than before. An organiser attributes the evolution of this electoral behaviour to social media. "Today, the big change is that the speed and accessibility of information means that you do not need a membership card to be connected. It circulates freely. It's on Facebook. It's on Twitter".

He notes that "it is much more difficult to attract someone in a political party by saying that if 
you become a member you will have privileged access to a certain amount of information or to a certain quality of information". A rival organiser also confirms that people's behaviour has changed: "It's not just generational, they buy a product". He adds that this has implications on the level of volunteering and on voters' motivation:

\section{When we look at the beginning of the 1970 s, we had a lot of people. People were willing to go door-to-door to meet voters. We had people on the ground, they needed to touch each other. The communications were person-to-person. (...) Today, we do marketing.}

In sum, "people seek a product and are less loyal" which means that parties must rely on voters' profiling and targeting.

\section{Increased use of digital technology in 2018}

The IT turn in Québec partisan organisations is real. One organiser goes so far as to say that most of the volunteer work that was central in the past is now done digitally. According to him, "any young voter who uses Facebook, is now as important, if not more, than a party activist". This comment reinforces the notion that any communication with an elector must now be personalised:

\section{Now we need competent people in computer science, because we use platforms, email lists. When I send a message reminding to newly registered voters that it will be the first time they will vote, I am speaking directly to them.}

To achieve this micro-targeting, party databases are updated constantly. An organiser states that: "Our job is to feed this database with all the tools like surveys, etc... In short, we must bomb the population with all kinds of things, to acquire as much data as possible". For example, Québec solidaire and the Coalition avenir Québec broadly used partisan e-petitions to feed their database (Bélair-Cirino, 2017). There are neither rules nor legislation that currently limit the collection and use of this personal information if it is collected through a partisan online petition or website.

\section{Old political objectives - new digital techniques}

In accordance with the current literature on the hybridisation of electoral campaigns (Chadwick, 2013; Giasson et al., 2019), many respondents indicate that the integration of digital tools associated with data marketing has changed the way things are done. This also had an effect on the internal party organisation, as well as on the tasks given to members on the ground. An organiser explains how this evolution took place in just a few years:

Before, we had a field organisation sector, with people on the phones, distributors, all that. We had communication people, we had people distributing content. (...) Right now, we have to work with people that are not there physically and with something that I will not necessarily control.

An organiser from another political party is more nuanced: "We always need people to help us find phone numbers, we always need people to make calls". He confirms, however, that 
communication tactics changed radically:

The way to target voters in a riding has changed. The way to start a campaign, to canvas, has changed. The technological tools at our disposal means that we need more people who are able to use them and who have the skills and knowledge to use the new technological means we have to reach the electorate.

Another organiser adds that it is now important to train activists properly for their canvassing work. According to her: "We need to give activists digital tools and highly technological support tools that make their lives easier". She adds that: "Everything is chained with intelligent algorithms that will always target the best customer, always first, no matter what...".

New digital technologies and tools are therefore used to maximise efficiency and resources. The tasks entrusted to activists also change. For another organiser, mobilisation evolves with technology: "We used to rely on lots of people to reach for electors". He now sees that people are reached via the internet and that this new reality is not without challenges: "we are witnessing a revolution where new clients do not live in the real world...". It then becomes difficult to meet them in real life, off-line.

Another organiser confirms having "a different canvas technique using social media and other tools". According to him:

\section{Big data is already outdated. We are talking about smart data. These data are used efficiently and intelligently. How do we collect this data? (...) We used to do a lot of tally by door-to-door or by phone. Now we do a lot of capture. The emails are what interest me. I am not interested in phone numbers anymore, except cell phones.}

An experienced organiser observes that "this has completely changed the game. Before, we only had one IT person, now I have three programmers". He adds that "liaison officers have become press officers". This change also translates in the allocation of resources and the integration of new profiles of employees for data management. It brought a new set of digital strategists into war rooms. These new data analysts have knowledge in data management, applied mathematics, computer science and software engineering. They are working alongside traditional field organisers, sometimes even replacing them at the decision table.

\section{Second thoughts}

Organisers themselves raise democratic and ethical concerns related to the digital evolution of their work. One of them points out that they face ethical challenges. He openly wonders about the consequences of this gathering of personal information: "It's not because we can do something that we have to do it. With the list of electors, there are many things that can be done. Is it ethical to do it? At some point, you have to ask that question". He points out that new technologies are changing at a rapid pace and that with "each technology comes a communication opportunity". The question is now "how can we appropriate this technology, this communication opportunity, and make good use of it".

Reflecting upon the lack of regulation on the use of personal data by parties in Québec, an organiser added that: "We have the right to do that, but people do not like it". For him, this issue is "more than a question of law, there could be a question of what is socially acceptable". 
Another organiser points out that the digital shift could also undermine intra-party democracy. Speaking about the role of activists, he is concerned that "they feel more like being given information that has been chewed on by a small number of people than being collected by more people in each constituency". He notes that the technological divide is also accompanied by a generational divide within the activist base:

\section{The activist who is older, we will probably have less need of him. The younger activist is likely to be needed, but in smaller numbers. (...) Because of the technological gap, it's a bit of a vicious circle, that is also virtuous. The more we try to find technological means that will be effective, the less we need people.}

Still, democratically, the line can be very thin between mobilisation and manipulation. Reflecting on a not-so-distant future, this organiser spoke of the many possibilities data collection could provide parties with:

\section{These changes bring us into a dynamic that the Americans call 'activation fields'. (...) From the moment we have contact with someone, what do we do with this person, where does she go? (...) This gives incredible arborescence, but also incredible opportunities.}

He concludes that: "Today, the world does not realise how all the data is piling up on people and that this is how elections are won now". Is there a limit to the information a party could collect on an elector? This senior staffer does not believe so. He adds: "If I could know everything you were consuming, it would be so useful to me and help mobilise you".

Québec's main political parties completed their digital shift in preparation for the 2018 election. Our interviews show that this change was significant. From an internal democracy perspective, digital technologies and data marketing practices help respond to the decline of activism and membership levels observed in most Québec parties (Montigny, 2015). This can also lead to frustration among older party activists who would feel less involved. On the other hand, from a data protection perspective we note that in the absence of a rigorous regulatory framework, parties in Québec can do almost anything. As a result, they collect a significant amount of unprotected personal data. The pace at which this change is taking place and the risks it represents for data security even lead some political organisers to question their own practices. As the next section indicates, Québec is lagging behind in adapting the data marketing practices of political parties to contemporary privacy standards.

\section{THE PROTECTION OF PERSONAL INFORMATION OVER TIME}

The data contained in the Québec list of electors has been the cornerstone of all political parties' electioneering efforts for many years and now form the basis of their respective databases of voter information. It is from this list that they are able, with the addition of other information collected or purchased, to file, segment and target voters. An overview of the legislative amendments concerning the disclosure of the information contained in the list of electors reveals two things: (1) its relatively recent private nature, and (2) the fact that the ability for political parties to collect and use personal data about voters never really seems to have been questioned until recently. Parties mostly reacted by insisting on self-regulation (Élections Québec, 2019). 
With regard to the public/private nature of the list of electors, we should note that prior to 1979 it was displayed in public places. Up to 2001, the list of electors of a polling division was even distributed to all voters in that section. Therefore, the list used to be perceived as a public document in order to prevent electoral fraud. Thus, citizens were able to identify potential errors and irregularities.

From 1972 on, the list has been sent to political parties. With the introduction of a permanent list of electors in 1995, political parties and MNAs were granted, in 1997, the right to receive annual copies of the list for verification purposes. Since 2006, parties receive an updated version of the list three times a year. This facilitates the update of their computerised voter databases. It should also be noted that during election periods, all registered electoral candidates are granted access to the list and its content.

Thus, while public access to the list of electors has been considerably reduced, political parties' access has increased in recent years. Following legislative changes, some information has been removed from the list, the age and profession of the elector for instance. Yet, the Québec list remains the most exhaustive of any Canadian jurisdiction in terms of the quantity of voter information it contains, indicating the name, full address, gender and date of birth of each elector (Élections Québec, 2019, p. 34).

From a legal perspective, Québec parties are not subject to the "two general laws that govern the protection of personal information, namely the Act respecting access to documents held by public bodies and the protection of personal information, which applies in particular to information held by a public body, and the Act respecting the protection of personal information in the private sector, which concerns personal information held by a person carrying on a business within the meaning of section 1525 of the Civil Code of Québec" (Élections Québec, 2019, p. 27). Indirectly, however, this law would apply when a political party chooses to outsource some of its marketing, data collection or digital activities to a private sector firm.

Moreover, the Election Act does not specifically define which uses of data taken from the list of electors are permitted. It merely provides some general provisions. Therefore, parties cannot use or communicate a voter's information for purposes other than those provided under the Act. It is also illegal to communicate or allow this information to be disclosed to any person who is not lawfully entitled to it.

Instead of strengthening the law, parties represented in the National Assembly first chose to adopt their own privacy and confidentiality policies. This form of self-regulation, however, has its limits. Even if they appear on their websites, these norms are usually not easy to find and there is no way to confirm that they are effectively enforced by parties. Only the Coalition avenir Québec and the Québec Liberal Party offer a clear link on their homepage. 3 We analysed each of these according to five indicators: the presence of 1) a definition of what constitutes personal information, 2) a reference to the type of use and sharing of data, 3) methods of data collection, 4) privacy and security measures that are taken and 5) the possibility for an individual to withdraw his or her consent and contact the party in connection with his or her personal information.

Table 1: Summary of personal information processing policies of parties represented at the National Assembly of Québec 


\begin{tabular}{|c|c|c|c|c|}
\hline & CAQ & PLQ & QS & PQ \\
\hline $\begin{array}{c}\text { Definition } \\
\text { of personal } \\
\text { information }\end{array}$ & $\begin{array}{l}\text { Identifies a } \\
\text { person (contact } \\
\text { information, } \\
\text { name, address } \\
\text { and phone } \\
\text { number). }\end{array}$ & $\begin{array}{l}\text { Identifies a } \\
\text { natural person } \\
\text { (the name, date } \\
\text { of birth, email } \\
\text { address and } \\
\text { mailing address } \\
\text { of that person, if } \\
\text { the person } \\
\text { decides to } \\
\text { provide them). }\end{array}$ & $\begin{array}{l}\text { About an } \\
\text { identifiable } \\
\text { individual that } \\
\text { excludes } \\
\text { business contact } \\
\text { information } \\
\text { (name, date of } \\
\text { birth, personal } \\
\text { email address, } \\
\text { and credit card). }\end{array}$ & \\
\hline $\begin{array}{l}\text { Strategic } \\
\text { use and } \\
\text { sharing of } \\
\text { data } \\
\text { protocols }\end{array}$ & $\begin{array}{l}\text { - To provide } \\
\text { news and } \\
\text { information } \\
\text { about the party. } \\
\text { - Can engage } \\
\text { third parties to } \\
\text { perform certain } \\
\text { tasks (processing } \\
\text { donations, } \\
\text { making phone } \\
\text { calls and } \\
\text { providing } \\
\text { technical } \\
\text { services for the } \\
\text { website). } \\
\text { - Written } \\
\text { contracts include } \\
\text { clauses to protect } \\
\text { personal } \\
\text { information. }\end{array}$ & $\begin{array}{l}\text { - To contact } \\
\text { including by } \\
\text { newsletter to } \\
\text { inform news and } \\
\text { events of the } \\
\text { Party. } \\
\text { - To provide a } \\
\text { personalised } \\
\text { navigation } \\
\text { experience on the } \\
\text { website with } \\
\text { targeted } \\
\text { information } \\
\text { according to } \\
\text { interests and } \\
\text { regions. }\end{array}$ & $\begin{array}{l}\text { - May disclose } \\
\text { personal } \\
\text { information to } \\
\text { third parties for } \\
\text { purposes related } \\
\text { to the } \\
\text { management of } \\
\text { party activities } \\
\text { (administration, } \\
\text { maintenance or } \\
\text { internal } \\
\text { management of } \\
\text { data, } \\
\text { organisation of } \\
\text { an event). } \\
\text { - Not sell, trade, } \\
\text { lend or } \\
\text { voluntarily } \\
\text { disclose to third } \\
\text { parties the } \\
\text { personal } \\
\text { information } \\
\text { transmitted. }\end{array}$ & $\begin{array}{l}\text { - To improve } \\
\text { the content of } \\
\text { the website } \\
\text { and use for } \\
\text { statistical } \\
\text { purposes. }\end{array}$ \\
\hline $\begin{array}{l}\text { Data } \\
\text { collection } \\
\text { method }\end{array}$ & $\begin{array}{l}\text { - Following a } \\
\text { contact by email. } \\
\text { - Following the } \\
\text { subscription to a } \\
\text { communication. } \\
\text { - After filling out } \\
\text { an information } \\
\text { request form or } \\
\text { any other form } \\
\text { on a party page, } \\
\text { including polls, } \\
\text { petitions and } \\
\text { party } \\
\text { applications. } \\
\text { - The party } \\
\text { reserves the right } \\
\text { to use cookies on } \\
\text { its site. }\end{array}$ & $\begin{array}{l}\text { - Collected only } \\
\text { from an online } \\
\text { form provided } \\
\text { for this purpose. }\end{array}$ & & \\
\hline
\end{tabular}




\begin{tabular}{|c|c|c|c|c|}
\hline & CAQ & PLQ & QS & PQ \\
\hline $\begin{array}{c}\text { Privacy and } \\
\text { Security of } \\
\text { data }\end{array}$ & $\begin{array}{l}\text { - Personal } \\
\text { information is } \\
\text { not used for } \\
\text { other purposes } \\
\text { without first } \\
\text { obtaining } \\
\text { consent. From } \\
\text { data provider. } \\
\text { - Personal } \\
\text { information may } \\
\text { be shared } \\
\text { internally } \\
\text { between the } \\
\text { party's head } \\
\text { office and its } \\
\text { constituency } \\
\text { associations. }\end{array}$ & $\begin{array}{l}\text { - Respect the } \\
\text { confidentiality } \\
\text { and the } \\
\text { protection of } \\
\text { personal } \\
\text { information } \\
\text { collected and } \\
\text { used. } \\
\text { - Only people } \\
\text { assigned to } \\
\text { subscriptions } \\
\text { management or } \\
\text { communications } \\
\text { with subscribers } \\
\text { have access to } \\
\text { information. } \\
\text { - Protection of } \\
\text { information } \\
\text { against } \\
\text { unauthorized } \\
\text { access attempts } \\
\text { with a server that } \\
\text { is in a safe and } \\
\text { secure place. }\end{array}$ & $\begin{array}{l}\text { - Respect the } \\
\text { privacy and } \\
\text { confidentiality of } \\
\text { personal } \\
\text { information. } \\
\text { - Personal details } \\
\text { will not be } \\
\text { published or } \\
\text { posted on the } \\
\text { Internet in any } \\
\text { way except at the } \\
\text { explicit request } \\
\text { of the person } \\
\text { concerned. } \\
\text { - The } \\
\text { information is } \\
\text { sent in the form } \\
\text { of an encrypted } \\
\text { email message } \\
\text { that guarantees } \\
\text { confidentiality. } \\
\text { - No guarantees } \\
\text { that the } \\
\text { information } \\
\text { disclosed by the } \\
\text { Internet will not } \\
\text { be intercepted by } \\
\text { a third party. } \\
\text { - The site strives } \\
\text { to use } \\
\text { appropriate } \\
\text { technological } \\
\text { measures, } \\
\text { procedures, and } \\
\text { storage devices } \\
\text { to prevent } \\
\text { unauthorised use } \\
\text { or disclosure of } \\
\text { your personal } \\
\text { information. }\end{array}$ & $\begin{array}{l}\text { - No } \\
\text { information to } \\
\text { identify an } \\
\text { individual } \\
\text { unless he has } \\
\text { provided this } \\
\text { information } \\
\text { for this } \\
\text { purpose. } \\
\text { - Take } \\
\text { reasonable } \\
\text { steps to } \\
\text { protect the } \\
\text { confidentiality } \\
\text { of this } \\
\text { information. } \\
\text { - The } \\
\text { information } \\
\text { automatically } \\
\text { transmitted } \\
\text { between } \\
\text { computers } \\
\text { does not } \\
\text { identify an } \\
\text { individual } \\
\text { personally. } \\
\text { - Access to } \\
\text { collected } \\
\text { information is } \\
\text { limited only to } \\
\text { persons } \\
\text { authorized by } \\
\text { the party or by } \\
\text { law. }\end{array}$ \\
\hline $\begin{array}{l}\text { Withdrawal } \\
\text { of consent } \\
\text { and } \\
\text { information }\end{array}$ & $\begin{array}{l}\text { - Any person } \\
\text { registered on a } \\
\text { mailing list can } \\
\text { unsubscribe at } \\
\text { any time. } \\
\text { - Invitation to } \\
\text { share questions, } \\
\text { comments and } \\
\text { suggestions. }\end{array}$ & $\begin{array}{l}\text { - Ability to apply } \\
\text { to no longer } \\
\text { receive party } \\
\text { information at } \\
\text { any time. }\end{array}$ & $\begin{array}{l}\text { - Ability to } \\
\text { withdraw } \\
\text { consent at any } \\
\text { time on } \\
\text { reasonable } \\
\text { notice. }\end{array}$ & \\
\hline
\end{tabular}

In general, we find that three out of four parties offer similar definitions of the notion of personal information: the Coalition avenir Québec, the Liberal Party of Québec and Québec solidaire. Beyond this indicator, the information available varies from one party to another. Thus, voters have little information on the types of use of their personal data. Moreover, only the Coalition avenir Québec and Québec solidaire indicate that they can use a third party in the processing of data without having to state the purpose of this processing to the data providers. The Coalition avenir Québec is the only party that specifies its methods of data collection in more detail. Similarly, Québec solidaire is more specific with respect to the measures taken to 
protect the privacy and security of the data it collects. Finally, the Parti québécois does not specify the mechanism by which electors could withdraw their consent.

\section{CAMBRIDGE ANALYTICA AS A TURNING POINT}

Our analysis of media coverage of the partisan and electoral use of voter data in Québecreveals three main conclusions. First, even though Québec political parties, both at the provincial and municipal levels, began collecting, storing and using personal data on voters several years ago, news media attention on these practices is relatively new. Secondly, the dominant media frame on the issue seems to have changed over the years: after first being rather anecdotal, the treatment of the issue grew in importance and became more suspicious. Finally, the Cambridge Analytica scandal appears as a turning point in news coverage. It is this affair that will force parties and their strategists to explain their practices publicly for the first time (Bélair-Cirino, 2018), will put pressure on the government to react, and bring to the fore the concerns and demands of other organisations such as Élections Québec and the Commission d'accès à linformation du Québec, the administrative tribunal and oversight body responsible for the protection of personal information in provincial public agencies and private enterprises.

Interest in ethical and security issues related to data campaigning built up slowly in Québec's political news coverage. Already in 2012, parties used technological means to feed their databases and target the electorate (Giasson et al., 2019). However, it is in the context of the municipal elections in the Fall of 2013 that the issue of the collection and processing of personal data on voters was first covered in a news report. It was only shortly after the 2014 Québec elections that we found a news item dealing specifically with the protection of personal data of Québec voters. The Montréal-based newspaper Le Devoir reported that the list of electors was made available online by a genealogy institute. It was even possible to get it for a fee. The Drouin Institute - which released the list - estimated that about 20,00o people had accessed the data (Fortier, 2014).

Paradoxically, the following year, the media reported that investigators working for Élections Québec could not access the data of the electoral list for the purpose of their inquiry (Lajoie, 2015a). That same year, another anecdotal event made headlines: a Liberal MNA was asked by Élections Québec to stop using the voters list data to call his constituents to... wish them a happy birthday (Lajoie, 2015b). In the 2017 municipal elections, and even more so after the revelations regarding Cambridge Analytica in 2018, the media in Québec seemed to have paid more attention to data-driven electoral party strategies than to the protection of personal data by the parties.

For instance, in the hours following the revelation of the Cambridge Analytica scandal, political reporters covering the National Assembly in Québec quickly turned their attention to the leadership of political parties, asking them to report on their respective organisations' digital practices and about the regulations in place to frame them. Simultaneously, Élections Québec, which had been calling for stronger control of personal data use by political parties since 2013, expressed its concerns publicly and fully joined the public debate. As a way to mark its willingness to act on the issue, the liberal government introduced a bill at the end of the parliamentary session, the last of this parliament. The bill was therefore never adopted by the House, which was dissolved a few days later, in preparation for the next provincial election.

Political reporters in Québec have since then paid sustained attention to partisan practices regarding the collection and use of personal information. In their coverage of the 2018 election campaign, they widely discussed the use of data by leaders and their political parties. Thus, 
while the Cambridge Analytica affair did not directly affect Québec political parties, it nevertheless appears as a shifting point in the media coverage of the use of personal data for political purposes.

Media framing of the issue also evolved over the studied period, becoming more critical and suspicious of partisan data marketing with time. Before the Cambridge Analytica case, coverage rarely focused on the democratic consequences or privacy and security issues associated with the use of personal data for political purposes. Initial coverage seems to have been largely dominated by the story depicting how parties were innovating in electioneering and on how digital technologies could improve electoral communication. Journalists mostly cited the official discourse of political leaders, their strategists or of the digital entrepreneurs from tech companies who worked with them.

An illustrative example of this type of coverage can be found in an article published in September 2013 during municipal elections held in Québec. It presents a portrait of two Montréal-based data analysis companies - Democratik and Vote Rapide - offering technological services to political parties (Champagne, 2013). Their tools were depicted as simple databases fed by volunteers, mainly intended for the identification of sympathisers to facilitate the get-out-the-vote operations (GOTV). It emphasised the affordability and universal use of these programmes by parties, and even indicated that one of them had been developed with the support of the Civic Action League, a non-profit organisation that helps fight political corruption.

However, as the years passed, a change of tone began to permeate the coverage, especially in the months building up to the 2018 general election. A critical frame became more obvious in reporting. It even used Orwellian references to data campaigning in titles such as... "Political parties are spying on you" (Castonguay, 2015) "They all have a file on you" (Joncas, 2018), "What parties know about you" (Croteau, 2018), or "Political parties exchange your personal details" (Robichaud, 2018). In a short period of time, data campaigning had gone from cool to dangerous.

\section{CONCLUSION}

Québec political parties began their digital shift a few years later than their Canadian federal counterparts. However, they have adapted their digital marketing practices rapidly; much faster in fact than the regulatory framework. For the 2018 election, all major parties invested a great deal of resources to be up to date on data-driven campaigning.

To maximise the return on their investment in technology, they must now "feed the beast" with more data. Benefiting from weak regulation over data marketing, this means that they will be able to gather even more personal information in the years to come, without having to explain to voters what their data are used for or how they are protected. In addition, parties are now involving an increasing number of volunteers in the field for the collection of digital personal information, which also increases the risk of data leakage or misuse.

They have, so far, implemented that change with very limited transparency. Up until now, research in Canada has not been able to identify precisely what kind of information is collected or how it is managed and protected. Canadian political strategists have been somewhat forthcoming in explaining how parties collect and why they use personal data for electoral 
purposes (see for instance Giasson et al., 2019; Giasson and Small, 2017; Flanagan, 2014; Marland, 2016). They however remain silent on the topics of regulation and data protection.

This lack of transparency is problematic in Canada since party leaders who win elections have much more internal powers in British parliamentary systems then in the US presidential system. They control the executive and legislative branches as well as the administration of the party. This means that there is no firewall and real restrictions to the use of data collected by a party during an election once it arrives in office. In that regard, it was revealed that the Office of the Prime Minister of Canada, Justin Trudeau, used its party's database to vet judges' nominations (Bergeron, 2019). The same risks apply to Québec.

It is in this context that Élections Québec and the Access to Information Commission of Québec have initiated a broad reflection on the electoral use of personal data by parties. In 2018, following a leak of personal data from donors of a Montréal-based municipal party, the commission contacted the campaign to "examine the measures taken to minimise risks". The commission took the opportunity to "emphasise the importance of political parties being clearly subject to privacy rules, as is the case in British Columbia" (Commission d'accès à l'information du Québec, 2018).

In a report published in February 2019, the Chief Electoral Officer of Québec presented recommendations that parties should follow in their voter data collection and analysis procedures (Élections Québec, 2019). It suggested that provincial and municipal political parties be submitted to a general legislative framework for the protection of personal information. Heeding these calls for change, Québec's new Minister of Justice and Democratic Reform announced, in November 2019, plans for an overhaul of the province's regulatory framework on personal data and privacy, which would impose stronger regulations on data protection and use and would grant increased investigation powers to the head of the Commission d'accès à l'information. All businesses, organisations, governments and public administrations operating in Québec and collecting personal data would be covered under these news provisions and could be subjected to massive fines for any form of data breach in their systems. Aimed at ensuring better control, transparency and consent of citizens over their data, these measures, which will be part of a bill introduced in 2020 to the National Assembly, were said to also apply to political parties (Croteau, 2019). However, as this article goes to print, the specific details of these new provisions aimed at political parties remain unknown.

This new will to regulate political parties is the result of a perfect storm where three factors came into play at the same time. Thus, in addition to the rapid integration of new data collection technologies by Québec's main political parties, there was increased pressure from regulatory agencies and an international scandal that changed the media framing of the political use of personal data.

Well beyond the issue of privacy, data collection and analysis for electoral purposes also change some features of our democracy. Technology replacing activists translates in major intra-party changes. In a parliamentary system, this could increase the centralisation of power around party leaders who now rely less on party members to get elected. This would likely be the case in Québec and in Canada.

Some elements also fuel resistance to change within parties, such as the dependence on digital technologies at the detriment of human contact, fears regarding the reliability of systems or data and the high costs generated by the development and maintenance of databases. For some, party culture also plays a role. A former political strategist who worked closely with former 
Québec Premier Pauline Marois declared in the media: "You know in some parties, we value the activist work done by old ladies who come to make calls and talk to each voter, one by one" (Radio-Canada, 2017).

As some of our respondents mentioned, parties may move from 'big data' to 'smart data' in coming years, as they adapt to or adopt novel technological tools. In an era of partisan flexibility, data marketing seems to have helped some parties find and reach their voters. A move towards 'smart data' may now also help them modify those voters' beliefs with even more targeted digital strategies. What might this mean for democracy in Québec? Will its voters be mobilised or manipulated when parties will use their data in upcoming campaigns? Are political parties on the edge of glory or of catastrophe? These questions should be central to the study of datadriven campaigning. 


\section{REFERENCES}

Baldwin-Philippi, J. (2017). The Myths of Data-Driven Campaigning. Political Communication, 34(7), 627-633. https://doi.org/10.1080/10584609.2017.1372999

Bashyakarla, V., Hankey, S., Macintyre, S., Rennó, R., \& Wright, G. (2019). Personal Data: Political Persuasion. Inside the Influence Industry. How it works. Berlin: Tactical Tech. Retrieved from https://cdn.ttc.io/s/tacticaltech.org/Personal-Data-Political-Persuasion-Howit-works_print-friendly.pdf

Bélair-Cirino, M. (2018). Inquiétude à Québec sur les banques de données politiques [Concern in Quebec City about Political Databanks]. Le Devoir. Retrieved from

https://www.ledevoir.com/societe/523240/donnees-personnelles-inquietude-a-quebec

Bélair-Cirino, M. (2017, April 15). Vie privée - Connaître les électeurs grâce aux petitions [Privacy - Getting to know voters through petitions]. Le Devoir. Retrieved from https://www.ledevoir.com/politique/quebec/496477/vie-privee-connaitreles-electeurs-grace-aux-petitions

Bergeron, P. (2018, May 26). Le Parti québécois se dote d'une «Force bleue» pour gagner les élections [The Parti Québécois has a "Force Bleue" to win elections]. La Presse. Retrieved from https://www.lapresse.ca/actualites/politique/politique-quebecoise/201805/26/01-5183364le-parti-quebecois-se-dote-dune-force-bleue-pour-gagner-les-elections.php

Bergeron, É. (2019, April 24). Vérification politiques sur de potentiels juges: l'opposition crie au scandale [Political checks on potential judges: Opposition cries out for scandal]. TVA Nouvelles. Retrieved from https://www.tvanouvelles.ca/2019/04/24/verification-politiques-sur-depotentiels-juges-lopposition-crie-au-scandale

Bennett, C. J. (2018). Data-driven elections and political parties in Canada: privacy implications, privacy policies and privacy obligations. Canadian Journal of Law and Technology, 16(2), 195-226. Available at

https://papers.ssrn.com/sol3/papers.cfm?abstract_id=3146964

Bennett, C. J. (2016). Voter databases, micro-targeting, and data protection law: can political parties campaign in Europe as they do in North America? International Data Privacy Law, 6(4), 261-275. https://doi.org/10.1093/idpl/ipw021

Bennett, C. J. (2015). Trends in voter surveillance in Western societies: privacy intrusions and democratic implications. Surveillance \& Society, 13(3-4), 370-384.

https://doi.org/10.24908/ss.v13i3/4.5373

Bennett, C. J. (2013). The politics of privacy and the privacy of politics: Parties, elections and voter surveillance in Western democracies. First Monday, 18(8).

https://doi.org/10.5210/fm.v18i8.4789

Blais, A., \& A. Robillard. (2017, October 4). 1 Million \$ pour un logiciel électoral [1 Million for election software]. Le Journal de Montréal. Retrieved from

https://www.journaldemontreal.com/2017/10/04/1-million--pour-un-logiciel-electoral

Cadwalladr, C., \& Graham-Harrison, E. (2018, March 17). Revealed: 50 million Facebook profiles harvested for Cambridge Analytica in major data breach. The Guardian. Retrieved from 
On the edge of glory (...or catastrophe): regulation, transparency and party democracy in data-driven campaigning in Québec

https://www.theguardian.com/news/2018/mar/17/cambridge-analytica-facebook-influenceus-election

Carlile, C. N. (2017). Data and Targeting in Canadian Politics: Are Provincial Parties Taking Advantage of the Latest Political Technology? [Master Thesis, University of Calgary]. Calgary: University of Calgary. https://doi.org/10.11575/PRISM/5226

Castonguay, A. (2015, September 14). Les partis politiques vous espionnent [The political parties are spaying on you]. L'Actualité. Retrieved from https://lactualite.com/societe/les-partispolitiques-vous-espionnent/

Champagne, V. (2013, September 25). Des logiciels de la Rive-Nord pour gagner les élections [Rive-Nord software to win elections]. Ici Radio-Canada.

Commission d'accès à l'information du Québec. (2018, April 3). La Commission d'accès à l'information examinera les faits sur la fuite de données personnelles de donateurs du parti Équipe Denis Coderre [The Commission d'accès à l'information will examine the facts on the leak of personal data of Team Denis Coderre donors]. Retrieved from http://www.cai.gouv.qc.ca/la-commission-dacces-a-linformation-examinera-les-faits-sur-la-fui te-de-donnees-personnelles-de-donateurs-du-parti-equipe-denis-coderre/

Croteau, M. (2018, August 20). Ce que les partis savent sur vous [What the parties know about you]. La Presse+. Retrieved from

http://mi.lapresse.ca/screens/8a829cee-9623-4a4c-93cf-3146a9c5f4cc__C___o.html

Croteau, M. (2019, November 22). Données personnelles: un chien de garde plus. Imposant

[Personal data: one guard dog more. Imposing]. La Presse+. Retrieved from

https://www.lapresse.ca/actualites/politique/201911/22/01-5250741-

donnees-personnelles-un-chien-de-garde-plus-imposant.php

Del Duchetto, J.-C. (2016). Le marketing politique chez les partis politiques québécois lors des élections de 2012 et de 2014 [Political marketing by Quebec political parties in the 2012 and 2014 elections] [Master's thesis, University of Montréal]). Retrieved from http://hdl.handle.net/1866/19404

Delacourt, S. (2013). Shopping for votes. How politicians choose us and we choose them. Madeira Park: Douglas \& McIntyre.

Dobber, T., Trilling, D., Helberger, N. \& de Vreese, C. H. (2017). Two crates of beer and 40 pizzas: the adoption of innovative political behavioural targeting techniques. Internet Policy Review, 6(4). https://doi.org/10.14763/2017.4.777

Dufresne, Y., Tessier, C., \& Montigny, E. .(2019) Generational and Life-Cycle E $\square$ ects on Support for Quebec Independence. French politics, 17(1), 50-63. https://doi.org/10.1057/s41253-019ooo83-9

Ehrhard, T., Bambade, A., \& Colin, S. (2019). Digital campaigning in France, a Wide Wild Web? Emergence and evolution of the market and Its players. In A. M. G. Solo (Ed.), Handbook of Research on Politics in the Computer Age (pp. 113-126). Hershey (PA), USA: IGI Global. https://doi.org/10.4018/978-1-7998-0377-5.choo7

Élections Québec. (2019). Partis politiques et protection des renseignements personnels: 
exposé de la situation québécoise, perspectives comparées et recommandations [Political Parties and the Protection of Personal Information: Presentation of the Quebec Situation, Comparative Perspectives and Recommendations]. Retrieved from

https://www.pes.electionsquebec.qc.ca/services/setooo5.extranet.formulaire.gestion/ouvrir_fi chier.php?d=2002

Enli, G. \& Moe, H. (2013). Social media and election campaigns - key tendencies and ways forward. Information, Communication \& Society, 16(5), 637-645.

https://doi.org/10.1080/1369118x.2013.784795

Flanagan, T. (2014). Winning power. Canadian campaigning in the $21^{\text {st }}$ century. Montréal; Kingston: McGill-Queen's University Press.

Flanagan, T. (2010). Campaign strategy: triage and the concentration of resources. In H. MacIvor (Ed.), Election (pp. 155-172). Toronto: Emond Montgomery Publications.

Fortier, M. (2014, May 29). La liste électorale du Québec vendue sur Internet [Quebec's list of electors sold on the Internet]. Le Devoir. Retrieved from

https://www.ledevoir.com/societe/409526/la-liste-electorale-du-quebec-vendue-sur-internet

Giasson, T., \& Small, T. A. (2017). Online, all the time: the strategic objectives of Canadian opposition parties. In A. Marland, T. Giasson, \& A. L. Esselment (Eds.), Permanent campaigning in Canada (pp. 109-126). Vancouver: University of British Columbia Press.

Giasson, T., Le Bars, G. \& Dubois, P. (2019). Is Social Media Transforming Canadian Electioneering? Hybridity and Online Partisan Strategies in the 2012 Québec Election. Canadian Journal of Political Science, 52(2), 323-341.

https://doi.org/10.1017/s0008423918000902

Gibson, R. K. (2015). Party change, social media and the rise of 'citizen-initiated' campaigning. Party Politics, 21(2), 183-197. https://doi.org/10.1177/1354068812472575

Hersh, E. D. (2015). Hacking the electorate: how campaigns perceive voters. Cambridge: Cambridge University Press. https://doi.org/10.1017/cbo9781316212783

Howard, P. N, \& D. Kreiss. (2010). Political parties and voter privacy: Australia, Canada, the United Kingdom, and United States in comparative perspective. First Monday, 15(12).

https://doi.org/10.5210/fm.v15i12.2975

Joncas, H. (2018, July 28). Partis politiques : ils vous ont tous fichés [Political parties: they've got you all on file...]. Journal de Montréal. Retrieved from

https://www.journaldemontreal.com/2018/o7/28/partis-politiques-ils-vous-ont-tous-fiches

Karpf, D., Kreiss, D. Nielsen, R. K., \& Powers, M. (2015). The role of qualitative methods in political communication research: past, present, and future. International Journal of Communication, 9(1), 1888-1906. Retrieved from https://ijoc.org/index.php/ijoc/article/view/4153

Kreiss, D. (2016). Prototype politics. Technology-intensive campaigning and the data of democracy. Oxford, UK: Oxford University Press.

https://doi.org/10.1093/acprof:oso/9780199350247.001.0001 
Lajoie, G. (2015a, December 3). Les enquêteurs du DGEQ privés des informations contenues dans la liste électorale [DGEQ investigators deprived of the information contained in the list of electors]. Le Journal de Montréal. Retrieved from

https://www.journaldemontreal.com/2015/12/03/le-dge-prive-ses-propres-enqueteurs-des-inf ormations

Lajoie, G. (2015b, November 27). André Drolet ne peut plus souhaiter bonne fête à ses électeurs [André Drolet can no longer wish his constituents a happy birthday]. Le Journal de Québec. Retrieved from https://www.journaldequebec.com/2015/11/27/interdit-de-souhaiter-bonanniversaire-a-ses-electeurs

Langlois, S. (2018). Évolution de l'appui à l'indépendance du Québec de 1995 à 2015 [Evolution of Support for Quebec Independence from 1995 to 2015]. In A. Binette and P. Taillon (Eds.), La démocratie référendaire dans les ensembles plurinationaux (pp. 55-84). Québec: Presses de l'Université Laval.

Marland, A. (2016). Brand command: Canadian politics and democracy in the age of message control. Vancouver: University of British Columbia Press.

Marland, A., Giasson, T., \& Lees-Marshment, J. (2012). Political marketing in Canada. Vancouver: University of British Columbia Press.

McKelvey, F., \& Piebiak, J. (2018). Porting the political campaign: The NationBuilder platform and the global flows of political technology. New Media \& Society, 2O(3), 901-918.

https://doi.org/10.1177/1461444816675439

Montigny, E. (2015). The decline of activism in political parties: adaptation strategies and new technologies. In G. Lachapelle \& P. J. Maarek (Eds.), Political parties in the digital age. The Impact of new technologies in politics (pp. 61-72). Berlin: De Gruyter.

https://doi.org/10.1515/9783110413816-004

Munroe, K. B \& Munroe, H. D. (2018). Constituency campaigning in the age of data. Canadian Journal of Political Science,51(1), 135-154. https://doi.org/10.1017/Sooo8423917001135

Patten, S. (2017). Databases, microtargeting, and the permanent campaign: a threat to democracy. In A. Marland, T. Giasson, \& A. Esselment. (Eds.), Permanent campaigning in Canada (pp. 47-64). Vancouver: University of British Columbia Press.

Patten, S. (2015). Data-driven microtargeting in the 2015 general election. In A. Marland and T. Giasson (Eds.), 2015 Canadian election analysis. Communication, strategy, and democracy. Vancouver: University of British Columbia Press. Retrieved from http://www.ubcpress.ca/asset/1712/election-analysis2015-final-v3-web-copy.pdf

Pelletier, R. (1989). Partis politiques et socie'te' québe'coise [Political parties and Quebec society]. Montré al: Que' bec Ame' rique.

Radio-Canada. (2017, October 1). Episode of Sunday, October 1, 2017 [Television Series Episode] in Les Coulisses du Pouvoir [Behind the scenes of power]. ICI RD. Retrieved from https://ici.radio-canada.ca/tele/les-coulisses-du-pouvoir/site/episodes/391120/jolycharest-sondages

Robichaud, O. (2018, August 20). Les partis politiques s'échangent vos coordonnées 
personnelles [Political parties exchange your personal contact information]. Huffpost Québec. Retrieved from https://quebec.huffingtonpost.ca/entry/les-partis-politiques-sechangent-voscoordonnees-personnelles_qc_5cccc8ece4bo89f526c6fo7o

Salvet, J.-M. (2018, January 31). Entente entre le PLQ et Data Sciences: «Tous les partis politiques font ça», dit Couillard [Agreement between the QLP and Data Sciences: "All political parties do that," says Couillard]. Le Soleil. Retrieved from https://www.lesoleil.com/actualite/politique/ententeentre-le-plq-et-data-sciences-tous-les-partispolitiques-font-ca-dit-couillard-21fgb1b2703cdba5cd95e32e7ccc574f

Thomas, P. G. (2015). Political parties, campaigns, data, and privacy. In A. Marland and T. Giasson (Eds.), 2015 Canadian election analysis. Communication, strategy, and democracy (pp. 16-17). Vancouver: University of British Columbia Press. Retrieved from http://www.ubcpress.ca/asset/1712/election-analysis2015-final-v3-web-copy.pdf

Vaccari, C. (2013). Digital politics in western democracies: a comparative study. Baltimore: Johns Hopkins University Press.

Yawney, L. (2018). Understanding the "micro" in micro-targeting: an analysis of the 2018 Ontario provincial election [Master's thesis, University of Victoria]. Retrieved from https://dspace.library.uvic.ca//handle/1828/10437

\section{FOOTNOTES}

1. Even though there are 22 officially registered political parties in Québec, all independent and autonomous from their counterpart at the federal level, only four are represented at the National Assembly: CAQ, QLP, QS and PQ. Since the Québec political system is based on the Westminster model, each MNA is elected in a given constituency by a first-past-the-post ballot.

2. According to QS website (view July 2, 2019).

3. Websites viewed on 27 March 2019. 